\title{
AN ACTIVITY THEORY-BASED ANALYTIC FRAMEWORK FOR THE STUDY OF DISCOURSE IN SCIENCE CLASSROOMS' ${ }^{1}$
}

\author{
Rodrigo Drumond Vieira* \\ Gregory J. Kelly** \\ Silvania Sousa do Nascimento***
}

\begin{abstract}
In this paper we introduce a new framework and methodology to analyze science classroom discourse and apply it to a university physics education course. Two fields of inquiry were adapted to develop the framework: activity theory and linguistics. From activity theory we applied levels of analysis (activity, actions, and operations) to organize and structure the discourse analysis. From the field of linguistics we used resources from sociolinguistics and textual linguistics to perform analysis at the action and operation levels. Sociolinguistics gave us criteria to introduce contextualization cues into analysis in order to consider ways that participants segmented their classroom conversations. Textual linguistics provided a basis for categories of language organization (e.g., argumentation, explanation, narration, description, injunction, and dialogue). From this analysis, we propose an examination of a teacher's discourse moves, which we labeled Discursive Didactic Procedures (DDPs). Thus, the framework provides a means to situate these DDPs in different types of language organization, examine the roles such DDPs play in events, and consider the relevant didactic goals accomplished. We applied this framework to analyze the emergence and development of an argumentative situation and investigate its specific DDPs and their roles. Finally, we explore possible contributions of the framework to science education research and consider some of its limitations.
\end{abstract}

${ }^{*} \mathrm{PhD}$ in Education from Federal University of Minas Gerais. High school physics teacher of Secretary of State of Education of Minas Gerais, Brazil. E-mail: rodrigo_vdrumond@ yahoo.com.br

* * Professor of science education and the Associate Dean for Research, Outreach, Technology in the College of Education, Pennsylvania State University, USA. E-mail: gkelly@psu.edu

** * Professor of science education in the Faculty of Education, Director of Center of Scientific Divulgation, Federal University of Minas Gerais, Brazil. E-mail: silvania.nascimento@ gmail.com

Keywords: Discourse analysis methodology, activity theory, sociolinguistics, textual linguistics. 


\section{UMA ESTRUTURA ANALÍTICA BASEADA NA TEORIA DA ATIVIDADE PARA INVESTIGAR O DISCURSO EM SALAS DE AULA DE CIÊNCIAS}

RESUMO: Neste artigo introduzimos uma nova estrutura e metodologia para analisar o discurso em salas de aula de ciências e a aplicamos para analisar um curso de formação de professores de física. Dois campos de pesquisa foram adaptados para desenvolver a estrutura analítica: teoria da atividade e linguística. Da teoria da atividade aplicamos os níveis de análise (atividade, ações e operações) para organizar e estruturar as análises do discurso. Do campo da linguística utilizamos recursos da sociolinguística e da linguística textual para realizar análises nos níveis da ação e da operação. Da sociolinguística utilizamos as pistas de contextualização para considerar os modos pelos quais os participantes segmentaram as suas conversações de sala de aula. A linguística textual nos proveu com um conjunto de categorias para analisar os modos de organização da linguagem (e.g., argumentação, explicação, narração, descrição, injunção e diálogo). A partir dessa análise, propomos o exame dos movimentos discursivos do professor, os quais chamamos de Procedimentos Discursivos Didáticos (PDD). Deste modo, a estrutura oferece meios para situar esses PDD em diferentes modos de organização da linguagem, examinar as funções que os PDD cumprem em eventos e considerar os objetivos didáticos relevantes que são satisfeitos. A estrutura analítica foi aplicada para analisar a emergência e desenvolvimento de uma situação argumentativa e investigar os seus PDD específicos e as suas funções. Finalmente, exploramos as possíveis contribuições da estrutura para a pesquisa em educação em ciências e consideramos algumas das suas limitações.

Palavras-chave: Metodologia para análise do discurso, teoria da atividade, sociolinguística, linguística textual. 


\section{UNA ESTRUCTURA ANALÍTICA BASADA EN LA TEORÍA DE LA ACTIVIDAD PARA INVESTIGAR EL DISCURSO EN AULAS DE CLASE DE CIENCIAS}

RESUMEN: En este artículo introducimos una nueva estructura y metodología para analizar el discurso en aula de clases de ciencias y la aplicamos para analizar un curso de formación de profesores de física. Dos campos de investigación fueron adaptados para desarrollar la estructura analítica: teoría de la actividad y lingüística. De la teoría de la actividad aplicamos los niveles de análisis (actividad, acciones y operaciones) para organizar y estructurar los análisis del discurso. Del campo de la lingüística utilizamos recursos de la sociolingüística y de la lingüística textual para realizar análisis en los niveles de la acción y de la operación. La sociolingüística posibilitó utilizar las pistas de contextualización para considerar los modos por los cuales los participantes segmentaran sus conversaciones de aula de clase. La lingüística textual nos proveyó con un conjunto de categorías para analizar los modos de organización del lenguaje (e.g., argumentación, explicación, narración, descripción, imposición y diálogo). A partir de ese análisis, proponemos el examen de los movimientos discursivos del profesor, a los cuales llamamos de Procedimientos Discursivos Didácticos (PDD). De este modo, la estructura ofrece medios para situar esos PDD en diferentes modos de organización del lenguaje, examinar las funciones que los PDD cumplen en eventos y considerar los objetivos didácticos relevantes que son satisfechos. La estructura analítica fue aplicada para analizar la emergencia y desarrollo de una situación argumentativa e investigar sus PDD específicos y sus funciones. Finalmente, exploramos las contribuciones posibles de la estructura para la investigación en educación en ciencias y consideramos algunas de sus limitaciones.

Palabras-llave: Metodología para análisis del discurso, teoría de la actividad, sociolingüística, lingüística textual. 


\section{INTRODUCTION}

In recent years studies in science education have evinced the fundamental role of discursive interactions in teaching and learning in science classroom environments (Kelly, 2007). These studies are grounded in social and situated views of learning (Lave \& Wenger, 1991). From this perspective, meaning is (co) constructed and shared among students and teachers in specific social contexts, affording particular possibilities and constraints, which include the material and psychological conditions (e.g., the instruments available, the sign systems shared among individuals), motives, goals, roles and situated identities, division of labor, and outcomes. These are components of what Yrjö Engeström (1999) has called an activity system, a unit of analysis proposed by Cultural Historical Activity Theory that has its roots in Soviet psychology, mainly in Lev Vygotsky (1986) and Aleksei Leont'ev works (1978).

Leont'ev (1978) claims that internal and external activities have similar structure. From this point of view, the former structure is derived from the latter. In this sense, we consider the activity structure, as proposed by Leont'ev (1978), a departure point to analyze human activity in any social environment, including science classrooms. This position is justifiable because the structure proposed by Leont'ev takes into account the uniqueness of human activity.

Therefore, we argue that Leont'ev's structuring of activity in "levels" (i.e. activity, actions, and operations) is useful to segment classrooms discourse, in which the analysis made in one level can give context and feedback for understanding the others levels, in an iterative process of inquire. The segmentation of discourse is a quite important methodological step since analysts of discourse in science classrooms usually deal with a considerable amount of data (e.g. video and audio recordings of classrooms interactions, filed notes, interviews, and so on), especially in ethnographic oriented studies (e.g., Castanheira, Crawford, Dixon \& Green 2001).

However, the segmentation of discourse is traditionally relied on a time-scale criteria and thematic content change. The innovative character of our approach is due to its psychological basis to segment discourse - the levels of activity, as proposed by Leont'ev (1978). In this sense and according to the levels of the activity structure, the study of one level (e.g. actions) can give criteria to analysts perform studies in other levels (e.g. operations).

This new approach to map discourse in levels according to the activity structure is dialectical as is expected from an activity theory perspective. Wolff-Michael Roth \& Yew-Jin Lee (2007) described an interesting analogy for understanding the dialectical status of the relations between the levels of one activity. They explain that a relation is dialectical when any part presupposes all other parts, as is the case for the activity, actions and operations. In their words: 
When one examines a thread, it assumes one form, though on moving closer, one may note that there are actually two or more interwoven strands. Without these strands, there is no thread, which thus presupposes the strands it is composed of. At the same time, the strands are what and where they are only because they are part of a thread; they assume a higher order structure that they contribute to realizing in a concrete way [...] with greater magnification, one sees that the strands are actually composed of very short fibers. The strands again presuppose fibers, for without the fibers, strands would not exist. But similarly, in this configuration, the fibers presuppose the strand, for without it they may be functioning as something very different (pp. 196).

At this point, the question that arises is methodological: How can we perform a discourse analysis based on levels of the structure of activity, as proposed by Leont'ev (1978)? In the following paragraphs we will discuss briefly some of the literature regarding discourse in general and in science classrooms, in particular. Such a review is meant to clarify to the reader why we decided to propose a new analytical framework for the study of discourse in science classrooms. As we will show, the new proposed framework is based on activity theory in association with perspectives from the field of linguistics (i.e., resources from sociolinguistics and textual linguistics).

\section{WHY A NEW FRAMEWORK TO ANALYZE SCIENCE CLASSROOMS DISCOURSE?}

One emerging area of research interest regarding discourse is the study of argumentation in science classrooms (Jimenez-Aleixandre \& Erduran, 2008). Researchers now regard argumentation as a desirable discursive practice in science classrooms due to its potential to develop conceptual and epistemic understandings.

Although the importance to promote argumentation in science classrooms, we argue that argumentation should be situated "in" and "alongside" other forms of language organization, so analysts can understand how such forms provide spaces for the emergence of argumentation within certain didactic ${ }^{2}$ goals. Studies in textual linguistics offers several types of language organization, called 'sequences' by Jean-Michel Adam (1992), which are useful for analyzing science classroom discourse. Until recently, science education has paid little attention to the integration of the various sequences (e.g., argumentative, explicative ${ }^{3}$, dialogue, descriptive, injunctive $e^{4}$ and narrative) as part of a whole framework of analysis. We propose an approach that considers these sequences in relation to didactic goals and the means (i.e., the teacher's discursive procedures) by which teachers can accomplish such goals.

Also, as we showed elsewhere (Vieira \& Nascimento, 2009a) undergraduate physics students and physics teachers do not have a clear concept of an argumentative situation and how it differs from, for instance, an explicative one. They usually mix up characteristics of these two different situations, and do not possess clear ideas of which goals each one can accomplish, or how each discursive situation can be achieved and maintained. This lack of awareness 
poses a problem for science education researchers to consider and we believe that understanding the roles of different sequences in discourse in science classrooms can be fruitful to promote more awareness regarding the teachers' discursive practices.

Related to this discussion, we will comment some aspects of two important frameworks to analyze discourse in science classrooms due to their possibilities to promote and increase teachers and researchers' awareness about science teachers' discursive practices. Moreover, we will comment some of their limitations.

To understand explanations in science classrooms, Jon Ogborn, Gunther Kress, Isabel Martins and Kieran McGillicuddy (1996) proposed ways to describe how teachers create entities, ascribe properties to them, establish relations among them, and develop a kind of history or narrative with these entities. This helpful description can be applied to gain more conscious accounts of science classrooms explanations. However, in this framework "explanation" as a category is too broad, including under the same label various other types of language textual organization, such as narration and description. The problem here is to deal with the specificities of the range of sequences that are all included in the same wide category.

Another important framework was developed by Eduardo Mortimer and Phil Scott (2003) and it is based on sociocultural theory (Wertsch, 1991). This framework has been used as a tool to understand the relationships and tensions between dialogic and authoritative approaches in science teaching. It is useful for teachers to become aware of their own practices and to understand the place and the need of a real dialogic approach in science teaching. However, this framework was not developed to clarify distinctions between, for instance, argumentation and explanation. We believe that it is necessary to study the nuances of discursive practices within the categories the framework proposes (i.e., how the dialogic approach offered by the authors relates to argumentative and non-argumentative discourse). Like other approaches, Mortimer and Scott's microanalysis approach has roots in patterns of interactions IRE (Initiation from teacher - Response from student - Evaluation from teacher) and IRF (Initiation from teacher - Response from student - Feedback from teacher) (see Cazden, 2001; Mehan, 1979; Sinclair \& Coulthard 1975). Thus, this framework gives us little insight regarding the diversity of epistemic practices and about a teacher's procedures.

These frameworks focused on explanations and dialogical approaches work as different "research lens", offering possibilities to analysts focus on some important aspects of science classrooms discourse. Although the contributions they brought to the research field, we acknowledge that one relevant problem regarding discourse analysis is related to the validation of analysis. James Gee (1999) argues for the importance that discourse analysis be recognized by "insiders", that is, recognized by people being investigated. Ethnographic studies in science classrooms usually seek to achieve an "emic" perspective into 
analysis (Green \& Wallat, 1981), and we highlight in this endeavor the roles of the sociolinguistics approach (Gumperz, 1982). This "emic" perspective is recognized as a way to study discourse interactions taking into account the point of view of the participants of the group investigated; in our case, we are interested in the ways that the teacher and students segment their conversations in science classrooms environments by means of contextualization cues. In this sense, sociolinguistics approach provides means to perform such analyzes whose outcomes are not alien to participants.

Up to this point we have identified some salient research problems and questions for studies of discourse in science classrooms settings. As an alternative to address such problems and questions, our main purpose in this paper is to introduce an analytical discursive framework and a methodology based on activity theory and linguistics. Our proposed framework seeks to address, in an integrated and articulated way, important purposes and aspects that we have derived from our previous discussions: i.e., to consider ways to segment discourse according to the structure of human activity, as proposed by Leont'ev; to consider how textual organization of language can be related to didactic goals in actual discursive practices through an emic perspective; to understand how these didactic goals can be identified and how they can be accomplished by teacher's situated discursive procedures; and to understand how these discursive procedures are related to immediate conditions.

With these orientations in mind, we discuss the construction of the framework and illustrate its operationalization with our empirical data. The framework was developed from data collected in a Brazilian pre-service physics teacher education context, and from our theoretical foundations and research purposes, all of which will be discussed in more details in the next sections.

\section{THEORETICAL FOUNDATIONS}

The analytic framework draws from two main general theoretical bases: activity theory, and linguistics. A brief discussion of each one of these bases of analysis will be presented, including their relevance to the framework.

\section{Activity Theory}

The historical, dialectical, and material account of human development based on Marxist ideology had a great influence in the formulation of activity theory. From this perspective, human cognition and development are tied to practical activity, which provides the structure and content to internal activity. Thus, Leont'ev (1978) poses the inseparability between consciousness and external activity as a main claim that gives us the key to understand human 
uniqueness which is, in fact, a consequence of some important characteristics of human activity. The use of instruments (tools), the appropriation of knowledge historically accumulated by society, social endeavors with divisions of labor, and the emergence and use of language in social contexts are some of the characteristics that distinguish humans from other animals.

According to Leont'ev (1978), any human activity can be analyzed from its constitutive structure, which led us to consider in this study three "levels" for the discourse analysis (see Vieira \& Nascimento, 2011), each of which represents an authentic and unique reality: activity, action, and operation. We describe each in turn.

\section{Activity, originating in a need/motive}

Any activity has its origins in a need, whether it be biological or cultural (e.g., need to eat, need for leisure, etc). The needs are the departure point to any activity, but they are not capable, alone, of starting an activity and giving it a specific orientation. This only happens when a need meets one object that can satisfy it. This object could be material or ideal, and is called the object of activity, its motive. Leont'ev calls this an objectification process of the need, which is its 'filling' with content of the objective world. We can say that the motive is the stimulating agent of the activity, it is the "motor" for all actions that unfold from the activity, and it is the distinctive factor between different activities.

Since we consider that the teacher has different motivations for different classes due to his course plan and due to feedbacks from the students and cues from previous classes, in our proposed framework we associated the activity level with one whole class (e.g., see table 1, "Class Presentation Frame", 3 ${ }^{\text {rd }}$ column, in which each class was considered as one activity with its motive/ object which can be connected and viewed as the teacher's general goal for that class). The association of a motive with a general goal is foreseen by Leont'ev (1978) when dealing with a high degree of development of one activity, as is the case for teaching science. Thus, the "activity" (one class) is our unit of analysis for the consideration of the related levels (activity, actions and operations). In this sense, when we say that we are performing analysis at the action level, it means that we are focusing on actions, but always considered in relation to the whole activity they translate to reality.

\section{Action, relating to the isolation of a conscious goal}

With the advent of the division of labor, for any single activity individuals may resort to different processes, attaining partial results, which when integrated, lead to a common outcome that may meet one or all of the individuals' needs. Leont'ev calls these processes "actions", which are related to individuals' representations of an outcome, that is, a conscious goal. Then, each one of the actions is oriented by a previous or emerging idealized goal. In our framework the actions are mapped by the "narrations frame" (e.g., see "action boundary" in 
table 2 - and "Narrations of the discursive interactions of actors and ongoing discourse" for each action in table $3,5^{\text {th }}$ column).

Besides its intentional aspect (what must be achieved), all action also presents an operational aspect (how and by which means it can be achieved), and this is not determined by the goal itself, but by the objective conditions of its accomplishment. These considerations then lead to the operation level, which is the next point of discussion.

\section{Operation, relating to conditions}

As previously mentioned, any action develops within specific objective conditions, which determine the methods of accomplishing the action. Leont'ev calls these methods "operations". Leont'ev also argues for the independence of actions and operations: one action can be accomplished by different operations, which depend upon the immediate conditions. Additionally, the same operations can accomplish different actions.

Operations are usually unconscious and are subordinated to an action goal because they do not have their own goal. In general, operations are formed as conscious actions. With time they begin to structure more complex actions, losing in this process their intentional aspect, but maintaining their operational aspect, which becomes automated. To accomplish an operation the individual needs to know how to perform it and it is the reason why an operation is automatic, that is, without the need of intentional effort for its accomplishment. The operation level is represented in our framework by what we call "Discursive Didactic Procedures" (DDPs), as we explain in the following sections (table 4, last column, shows the teacher's discursive didactic procedures (DDPs) and the students' discursive procedures).

Our proposed framework articulates these levels (activity, action, operation) to map events in an iterative process of inquiry, in which each level gives context and feedback to the others. In this sense, the activity structure proposed by Leont'ev is useful to perform and organize analysis in science classroom contexts and provide cues for the analyst select events for more thorough analysis. Figure 1 is presented further and shows schematically the levels with examples from teaching context presented further in this paper.

\section{Application of Linguistic Theory}

The second part of our theoretical base is drawn from the field of linguistics. From this field of inquiry we used resources from sociolinguistics and textual linguistics to perform analysis in the action and operation levels. From sociolinguistics, we used contextualization cues in order to obtain the speakers' perspectives, developing an emic perspective, and through this perspective, considered ways that participants segmented their classroom conversations. From 
textual linguistics we used categories of language organization (e.g., argumentation, explanation, narration, description, injunction, and dialogue), which we employed to identify patterns in science classrooms discourse. We will discuss briefly the resources of analysis from sociolinguistics and textual linguistics which we used and adapted to construct the framework.

\section{Sociolinguistics}

Sociolinguistics provides tools for understanding language-in-use (i.e., discourse) within specific contexts (Hymes, 1974). With such an approach we examine how people create, convey, and understand meanings using language in situated social activities. The situated character of discourse is a central issue in sociolinguistics because meanings are not absolute in themselves, but are always relative and dependent on the sociocultural activity in which they are embedded. Furthermore, meanings are created and construed by people using language in socially appropriate ways. Such engagement in social activity through discourse provides opportunity for the construction of situated identities among participants. Thus, in different and situated activities people act, talk, and think in different ways.

Sociolinguistics provide us with tools to analyze such situated discourse and identify how speakers signal to each other (and thus to us as analysts) ways of segmenting and marking communication. Central to this approach is a recognition of the importance of contextualization cues such as prosody, intonation, pauses, eye gaze and so forth. Such contextualization often co-varies with changes in the content of speech. We acknowledge that much of the endeavor (and struggle) for science students pertains to learning how to perceive and respond to such cues and participate in appropriate ways in the science classroom discourse enacted and managed by their science teachers.

In previous studies, it is well established that discursive practices in science classrooms are episodic by nature (Lemke, 1990). In this sense, our framework draws from sociolinguistic contextualization cues to perform division of discourse in units that can be recognized by insiders.

\section{Textual Linguistics}

To identify patterns in science classroom discourse we examine how language is organized in the classroom discourse and develop a set of analytic categories based on activity theory. Textual linguistics is a research field that seeks to understand how language is organized beyond the level of the phrase, so that the structure of a number of propositions is considered holistically. Adam (1992) proposed calling these textual organizations of language "sequences."

Sequences are components of any discourse genre (we use the notion of discourse genre from the dialogical perspective of Bakhtin, 1986) and they are realized by macro-propositions (or phases) that are themselves constituted by a set of propositions (Bronckart, 1996). Each sequence has its own phases, and can be 
accomplished in more complete or incomplete ways. Adam (1992) defined each sequence in terms of a prototype. One segment of text can more or less approach a given prototype. For instance, the Toulmin's Argument Pattern (TAP) (Toulmin, 1958; Erduran, Simon, \& Osborne, 2004) can be seen as a viable prototype for an argumentative sequence.

In real texts and discourse, the complex discursive situations provide little opportunity for "pure" sequences, and thus we consider any given sequence a blend comprised of different aspects of various sequences. Nevertheless, even given the complexity of discourse, and the need to consider sequences blends, it is possible to characterize any given discourse segment by a dominant sequence type.

Based on the work of Egon Werlich (1976), Jean-Michel Adam (1992) and Jean-Paul Bronckart (1996), we acknowledge six types of sequences for the context of science classrooms: explicative, argumentative, descriptive, narrative, injunctive, and dialogue. From these sequence types, we derived six kinds of "discursive orientations"; that is, six dominant sequence types that can be identified within a given discourse segment (the action category). The name "discursive orientation" makes the case that we are characterizing each discourse segment (i.e., 'actions') by a dominant sequence type, while considering the possibilities and constrains to human action. Our definition for "discursive orientation" is similar to what Christian Plantin (2005) has called "orientation".

\section{THE COORDINATION OF THE THEORETICAL BASES}

We adapted these three broad theoretical bases to serve the purposes of making sense of our empirical data. Thus, our framework emerges as a kind of theoretical-methodological "soup" (Gee, 1999) which has its roots in a bricolage approach informing research (Kincheloe, 2001). As Gee notes, each "soup" created by one analytic approach reflects its specific choices and purposes. But at the same time one's "soup" has the potential to be used, adapted, and transformed by other analysts in order to meet their own data and research requirements.

In the next sections we will describe the context of the study and provide specific details regarding the methodological framework. In doing so, some of our data will be utilized to exemplify the categories and the concepts proposed in the framework. In this presentation we will also introduce some fundamental instruments for discourse analysis that our research group has developed and that were adapted to fit into our framework and make sense of our data. 


\section{THE CONTEXT INVESTIGATED}

We used an ethnographic orientation to collect data in a pre-service teacher physics methods course (Vieira, 2011). The course teacher educator has experience in teaching both science in basic education and in teacher education. The purpose of the course was to develop the pedagogical knowledge of the students through a variety of experiences. His experiences as a teacher and researcher led us to believe that he would be a good choice of instructor to research relevant discursive practices that could inform other practitioners. The course observed was taught over one semester in a reputable public university in Brazil. The course had 60 contact hours and was mandatory for all undergraduate students (hereafter referred to "students") majoring in physics teacher education. Classes were videotaped and field notes were taken. Additionally, two interviews with the teacher educator were conducted, one before the beginning of the course and one at the end.

Field notes had primary and complementary roles in analysis depending on the level of analysis being considered. For the activity they were the primary source for inferences. For other levels (actions and operations) they played a complementary role. Interviews with the teacher educator (hereafter called "teacher") had a complementary role for inferences we made in all levels of analysis, bringing the teacher's perspective for events being analyzed. In the first interview we sought to achieve a broad overview of the course from the teacher's point of view. In the second interview we used footage of videos to prompt the teacher's reflections about selected events.

The discourse within this course developed from discussions about theoretical texts from the field of education, and from science education in particular, and their consequences to teaching science. In addition, the course provided the students with an opportunity to observe experienced teachers at public schools, with whom they were able to share mutual experiences and knowledge. This stage had a total of 30 extra hours of field work in addition to the 60 course contact hours. Each student was asked to reflect upon experiences from the observation stage during course discussions. Students were evaluated based upon written reports regarding their experiences and work related to the observation stage, and additionally from written work they completed concerning the texts discussed. At the end of the course there was a written test.

For the purpose to illustrate the application of the framework we will present data and analysis from one specific class of this course (class 9). The class comprised 16 students; 14 male and 2 females. Most students were aged from 22 to 30 years old. They were in the final year of the degree program and the majority had a day job. In addition, they were mostly middle-class. The teacher's main goal for this class was to discuss learning processes from a Piagetian perspective and relate this perspective to physics teaching. 
In this paper the study of this class was accomplished in different levels of analysis (activity, actions, and operations) which are presented in three frames (e.g., tables 1, 3, and 4), each one related to a specific level of analysis.

\section{THE FRAMEWORK}

The concept of levels of analysis (activity, actions, and operations) proposed by Leont'ev (1978) was used in order to organize the structure of the social (publically recognizable) activity, as focused on the teaching events. The levels are mapped in different frames:

- Activities were mapped by "Class Presentation Frame" (1st frame, see table1)

- Actions in each class were mapped by "Narrations Frame" (2nd frame, see table 3)

- Operations were mapped by "Propositional Frame" (3rd frame, see table 4).

The frames were applied for different levels of detailed analysis, from broader analysis (first frame), passing through more detailed analysis (second frame), and ending with a very detailed account (third frame). In this sense, the frames work collectively for the selection of data for more thorough analysis. They are articulated to work in an integrated way, providing context and meaning for other frames categories, in an iterative and reflexive process of inquiry.

The framework's emic perspective was informed by considering ways that the participants partitioned their discourse through shifts in thematic content and through contextualization cues (such as intonation, pitch, pause, gesture and so forth, see Gumperz, 2001). This is an important methodological step since units of segmenting discourse can be validated (Gee, 1999) from the point of view of insiders.

Within the action level, our framework deals with the emic perspective using the teacher's contextualization cues (and also complementary criteria such as the teacher's injunctive propositions, presence of metadiscourse, and self-action articulation) to divide discourse into small segments from the teacher's perspective - which will be called 'actions'- to which are ascribed some properties, such as the dominant discursive orientation and didactic goals. Also, for each action and within the operation level, contextualization cues are utilised in our framework to divide turns of talk into propositional units, that is, units of meaning which are later grouped as teacher's Discursive Didactic Procedures (DDPs) (Vieira, 2011; Vieira \& Nascimento 2009b), which we consider as the means to action accomplishment. Thus, the action category is related to one didactic goal and a set of DDPs situated in a specific discursive orientation.

Each discursive orientation can be interpret of as a kind of psychological tool for human action and thought. Then, we recognize that each discursive 
orientation afford particular "learning opportunities" to the students, since the rules and the possibilities to engage into discourse in socially appropriate ways are dependent of the discursive orientation at stake. Thus, it can be viewed as an open-ended instrument that shapes individuals' speech contributions while at the same time being transformed and changed by their contributions.

Taking into account this discussion and some results of our own research (Vieira \& Nascimento, 2009a; Vieira \& Nascimento, 2008), we claim that each discursive orientation gives rise to a set of its own particular DDPs and DDPs roles. Thus, it is possible to map the DDPs and their roles in relation to "actions / didactic goals / discursive orientations" in order to identify patterns. This focus on DDPs may enable researchers and teachers to become more aware of classroom discourse. Through this awareness, the focus on discursive orientation can provide the field with a set of situated DDPs, which may become a reference for other teachers and as an instrument to promote reflection on their own practices. We consider our framework as one methodological way to consider the emergence of the demands of a research approach that takes into account the multiple discursive orientations and structures of the everyday discourse of science teaching.

In our framework these methodological steps evince the relationships between categories of activity theory and those from sociolinguistics and textual linguistics. We will show in the next sections the articulations of these categories and how they fit into the framework in each one of the levels of analysis.

\section{Activity, Need, and Motive}

The level of activity is mapped by what we call "Class Presentation Frame" for the entire course (it was created for all class sessions). Considering the fact that the teacher needs to teach, constituting schooling activity (that is realized inside schools and universities), we recognize that for different classes he may have different objects (motives) that stimulate and give rise to this activity. From this perspective, we recognize that the teacher's motivations are both due to cues from students and previous classes, along with his course plan and influenced by curriculum and institutions wider educational motives.

This frame was constructed primarily through our field notes; interviews and video were secondary sources. The motives inferred with the support of this frame are based on work accomplished (our "pragmatic approach") through discourse processes. Across events we characterized the each class and considered it the teacher's motive for that class. In order to achieve this global view, we use cues from field notes and from descriptions made for each class, which are presented in the third column of this frame.

As we will show in the following discussion, due to the focus of analysis of this paper, this first draft mapping also surfaces situations in which argumentation occurs. A small segment of this frame is shown in table 1. 
Table 1: Small segment of "Class Presentation Frame" (mapping activities) for classes 8 and $\mathbf{9}$

\begin{tabular}{|c|c|c|c|c|c|}
\hline $\begin{array}{l}\text { CLASS } \\
\text { NUMBER } \\
\text { Date }\end{array}$ & $\begin{array}{l}\text { CLASS } \\
\text { DURATION } \\
\text { (h:m:s) }\end{array}$ & $\begin{array}{l}\text { BRIEF DESCRIPTIONS } \\
\text { OF EACH ACTIVITY } \\
\text { (CLASS) }\end{array}$ & $\begin{array}{l}\text { TEACHER'S MOTIVES } \\
\text { Motives were inferred } \\
\text { from field notes and } \\
\text { from the descriptions } \\
\text { in the previous column }\end{array}$ & $\begin{array}{l}\text { ARGUMENTATIVE } \\
\text { SITUATIONS AND } \\
\text { CONTRAPOSITION } \\
\text { OF IDEAS MARKER } \\
\text { (PRESENTED IN } \\
\text { THE FORM OF A } \\
\text { QUESTION) } \\
\text { [Domain of knowledge } \\
\text { involved] }\end{array}$ & $\begin{array}{l}\text { ARGUMENTATIVE } \\
\text { SITUATION } \\
\text { DURATIONS } \\
\text { (h:m:s) }\end{array}$ \\
\hline $\begin{array}{l}8 \\
03 / 29\end{array}$ & $01: 36: 38$ & $\begin{array}{l}\text { Discussion regarding the } \\
\text { difficulty of acceptance of } \\
\text { trainees in schools; } \\
\text { Exposition of current } \\
\text { trends about the } \\
\text { nature of science; } \\
\text { Discussion regarding } \\
\text { classroom space, } \\
\text { its constituents, its } \\
\text { mediations and the } \\
\text { importance of noting } \\
\text { these aspects during the } \\
\text { observation stage; } \\
\text { _General } \\
\text { recommendations for } \\
\text { the accomplishment of } \\
\text { observation stage. }\end{array}$ & $\begin{array}{l}\text { Guidelines for the } \\
\text { observation stage }\end{array}$ & $\begin{array}{l}\text { (1) The } \\
\text { phenomenon of } \\
\text { apparent counter } \\
\text { rotating wheels } \\
\text { of a car happens } \\
\text { only when there } \\
\text { is incident light } \\
\text { oscillating or it } \\
\text { happens also with } \\
\text { solar light? } \\
\text { [Content } \\
\text { knowledge] }\end{array}$ & 00:02:09 \\
\hline $\begin{array}{l}9 \\
04 / 03\end{array}$ & $01: 35: 36$ & $\begin{array}{l}\text { Main goal (declared by } \\
\text { the teacher): discuss the } \\
\text { process of learning and } \\
\text { its relations to } \\
\text { physics from a } \\
\text { Piagetian approach; } \\
\text { _Task in small groups: } \\
\text { answer two questions } \\
\text { regarding how human } \\
\text { learning is accomplished; } \\
\text { _Discussion of the } \\
\text { students' answers } \\
\text { (teacher made many } \\
\text { interventions giving } \\
\text { explanations in terms of } \\
\text { Piaget's theory). }\end{array}$ & $\begin{array}{l}\text { Piagetian approach } \\
\text { to understand } \\
\text { learning }\end{array}$ & $\begin{array}{l}\text { (1) At the peak } \\
\text { point in a vertical } \\
\text { launching, the } \\
\text { projected ball has } \\
\text { stopped or it has } \\
\text { not stopped? } \\
\text { [Content } \\
\text { knowledge] } \\
\text { (2) Need for } \\
\text { conventions: must } \\
\text { conventions for } \\
\text { talking physics } \\
\text { come in the } \\
\text { beginning or } \\
\text { at the ending } \\
\text { of a teaching } \\
\text { sequence? } \\
\text { [Pedagogical } \\
\text { knowledge] }\end{array}$ & $00: 26: 00$ \\
\hline
\end{tabular}


In table 1 the first column indicates the class number and date; the second column shows the length of this class; the third presents brief descriptions for each class derived from field notes; the fourth indicates the teatcher's motives inferred from field notes; the fifth describes the argumentative situations identified and the contraposition of ideas marker, both of which are presented in the form of a question; finally, in the last column we show the length of the argumentative situations identified.

Given our particular interest in argumentation, we used the "Class Presentation Frame" to present instances of contraposition of ideas, as one criterion marker we have previously used for identification of argumentation in science classrooms (Vieira, 2011; Vieira \& Nascimento, 2009a). The other marker is reciprocal justifications, but it is not shown in this frame. As we discussed in recent work (Vieira \& Nascimento, 2009a) and based on the work of Michael Billig (1996), Patrick Charaudeau and Dominique Maingueneau (2002) and Christian Plantin (2005), these are essential criteria for identifying an authentic oral argumentation event in science classrooms. The use of the word 'authentic' is relevant since there are discursive orientations that can be mistakenly viewed as argumentations. In this sense, the criteria proposed are intended to ensure that the explicative and argumentative orientations can be well distinguished, as we mentioned earlier.

Our previous research has demonstrated how these markers are operational in identifying authentic oral argumentation in science classrooms and illustrated their use within contrasting argumentative and explicative discursive orientations (Vieira \& Nascimento, 2009a). The following text clarifies how both markers were used to identify argumentations in our data.

In applying the markers to our data, the first argumentative marker was made in situ as field notes. The researcher recorded each instance of "contraposition" to the left of the time-stamped field notes when any kind of discursive contradiction was perceived (i.e., two contrary ideas for the same topic, such as "it stops or it doesn't stop"). After data collection and in reviewing each one of the contraposition situations via video, the researcher then identified those instances among the contraposition situations when "reciprocal justifications" were evident. These situations were considered as argumentations and were recorded in the "Class Presentation Frame" which shows the contraposition of ideas marker in the form of a question. In addition, the Class Presentation Frame includes the relevant domain of knowledge involved and the temporal length of each argumentative situation.

\section{Actions as Related to Didactic Goals}

The level of actions is mapped by what we call "Narrations Frame". This is a process in which discourse is divided into segments through identification 
of teacher's contextualization cues (Gumperz, 1982) and also through teacher's injunctive propositions, metadiscourse, and self-action articulation. The divided segments are associated to one teacher's didactic goal and then considered as the teacher's actions. While watching the video in real time, narrations of the interactions and ongoing discourse are added. By doing this, a more impartial and descriptive view is attempted, that avoids evaluation and assessments at this point. Then, for each action we ascribe a category related to a specific mode of language textual organization, what we have called "discursive orientations". The essential idea is that for each action we can distinguish a dominant discursive orientation from cues taken from the narrations column and from the video.

One first approximate identification of discursive orientations is based on the criteria we derived from the work of Werlich (1976), Bronckart (1996) and Adam (1992) and are presented briefly in table 2. A small segment of the "Narrations Frame" is presented in table 3.

Table 2: Descriptions of categories for "Narrations Frame"

\begin{tabular}{|c|c|c|c|}
\hline \multicolumn{3}{|c|}{ CATEGORIES } & DESCRIPTIONS OF THE CATEGORIES \\
\hline \multirow{7}{*}{$\begin{array}{l}\text { Discursive } \\
\text { Orientations }\end{array}$} & \multicolumn{2}{|l|}{ Definition } & Modes of language organization in discourse \\
\hline & \multirow{6}{*}{$\begin{array}{l}\text { Criteria } \\
\text { to identify } \\
\text { discursive } \\
\text { orientations }\end{array}$} & Dialogue & Turns of talk - tendency to circumscribe all other discursive orientations \\
\hline & & $\underline{\text { Argumentative }}$ & Contraposition of ideas / reciprocal justifications (reasons) \\
\hline & & Explicative & $\begin{array}{l}\text { Often verbs in the present / statement of a problem or idea / } \\
\text { non-contraposition of ideas / justifications (reasons) }\end{array}$ \\
\hline & & Narrative & $\begin{array}{l}\text { Often verbs of change (run, grow, etc) in the past / transformation } \\
\text { and linearization of things in time - "telling a story" }\end{array}$ \\
\hline & & Descriptive & $\begin{array}{l}\text { Often non-changes verbs in the present or past / intense uses of } \\
\text { adjectives / comparison / situation of phenomena on space }\end{array}$ \\
\hline & & Injunctive & $\begin{array}{l}\text { Often verbs in the present and future / orders, suggestions, } \\
\text { recipes directed to students - control of behavior }\end{array}$ \\
\hline \multicolumn{3}{|c|}{ Action boundary } & $\begin{array}{l}\text { Determined through contextualization cues land also by the teacher's } \\
\text { injunctive propositions, metadiscourse and self-action articulation) }\end{array}$ \\
\hline \multicolumn{3}{|c|}{$\begin{array}{l}\text { Narrations of discursive } \\
\text { interactions in each action }\end{array}$} & $\begin{array}{l}\text { Researcher narrates what is happening, avoiding at this time } \\
\text { interpretations or evaluations. At this moment the analyst } \\
\text { should be more impartial }\end{array}$ \\
\hline \multicolumn{3}{|c|}{ Emergent themes } & Main themes developed within an action \\
\hline \multirow[t]{2}{*}{$\begin{array}{l}\text { Teacher's } \\
\text { action }\end{array}$} & \multicolumn{2}{|l|}{ Action name } & $\begin{array}{l}\text { Synthetic characterization of an action from } \\
\text { the point of view of the teacher }\end{array}$ \\
\hline & \multicolumn{2}{|c|}{ Pragmatic goal } & $\begin{array}{l}\text { The teacher's general goal, which can be inferred and confirmed } \\
\text { by analyst through monitoring discursive correlations between } \\
\text { actions and immediately conditions (what is discursively } \\
\text { accomplished). It could be explicit (spoken by the teacher) or } \\
\text { implicit (unspoken) }\end{array}$ \\
\hline
\end{tabular}


Table 3: A small segment of "Narrations Frame" (mapping actions) for class 9 (encompassing the actions 16, 17 and 18)

\begin{tabular}{|c|c|c|c|c|c|c|}
\hline \multicolumn{7}{|c|}{ CLASS 04/03 - PRIMARY SOURCE OF INFORMATION: VIDEO - SECONDARY SOURCES: FIELD NOTES AND INTERVIEWS } \\
\hline $\begin{array}{l}\mathrm{N}^{\circ} \text { ACTION } \\
\text { TIME } \\
\text { (h:m:s) } \\
\text { LENGTH } \\
\text { (h:m:s) }\end{array}$ & $\begin{array}{l}\text { DOMINANT } \\
\text { DISCURSIVE } \\
\text { ORIENTATIONS }\end{array}$ & $\begin{array}{l}\text { ORGANIZATION } \\
\text { OF } \\
\text { INTERLOCUTION } \\
\text { PAIRS }\end{array}$ & $\begin{array}{l}\text { ARRANGEMENT } \\
\text { OF } \\
\text { INTERLOCUTORS }\end{array}$ & $\begin{array}{l}\text { NARRATIONS OF THE DISCURSIVE INTERACTIONS OF ACTORS AND ONGOING } \\
\text { DISCOURSE } \\
\begin{array}{r}\text { Underline - contextualization cues } \\
\begin{array}{l}\text { land also the teacher's injunctive propositions, } \\
\text { metadiscourse and self-action articulation) signaling }\end{array} \\
\text { action change }\end{array}\end{array}$ & $\begin{array}{l}\text { TEACHER } \\
\text { ACTION } \\
\end{array}$ & $\begin{array}{l}\text { PG - PRAGMATIC GOALS } \\
\text { T- EMERGENT THEMES } \\
R \text { - RESEARCHER'S } \\
\text { OBSERVATIONS }\end{array}$ \\
\hline $\begin{array}{l}00: 53: 18 \\
00: 00: 42\end{array}$ & Descriptive & $\begin{array}{l}\text { Teacher - } \\
\text { students }\end{array}$ & $\begin{array}{l}\text { Teacher standing, } \\
\text { teaching whole } \\
\text { class, students } \\
\text { sitting }\end{array}$ & $\begin{array}{l}\text { The teacher lists what the coordinated elements are in the given example: } \\
\text { "possibility of decomposing the movement in infinitesimals, description of } \\
\text { velocity varying in time, description of a variable that explains how velocity } \\
\text { varies in time, establishing of a relationship of this change with the force that } \\
\text { acts on the ball" } \\
\qquad \text { The teacher decreases his voice and RUI asks to make a comment }\end{array}$ & $\begin{array}{l}\text { Presenting } \\
\text { elements that } \\
\text { are coordinated } \\
\text { in the given } \\
\text { example }\end{array}$ & $\begin{array}{l}\text { PG - Summarise information } \\
\text { T - Coordination of ideas } \\
\text { T - Classical mechanics } \\
R-\text { The teacher makes } \\
\text { references to drawings on } \\
\text { the whiteboard }\end{array}$ \\
\hline $\begin{array}{l}00: 54: 00 \\
00: 01: 00\end{array}$ & Dialogue & $\begin{array}{l}\text { Teacher - } \\
\text { students }\end{array}$ & $\begin{array}{l}\text { Teacher standing, } \\
\text { teaching whole } \\
\text { class, students } \\
\text { sitting }\end{array}$ & $\begin{array}{l}\text { RUI states he already saw people saying in national exam corrections and on } \\
\text { TV that the ball stops at the peak point of its trajectory in an upward launching } \\
\text { Teacher articulates and justifies two contradictory points of view about } \\
\text { what means a ball be stopped and then affirm the ambiguity of this } \\
\text { question } \\
\text { The teacher takes a long pause, RUI takes the floor to speak }\end{array}$ & $\begin{array}{l}\text { Problematizing } \\
\text { a question }\end{array}$ & $\begin{array}{l}\text { PG - Promote argumentation } \\
\mathrm{T} \text { - Classical mechanics }\end{array}$ \\
\hline $\begin{array}{l}00: 55: 00 \\
00: 03: 00\end{array}$ & Argumentative & $\begin{array}{l}\text { Teacher - } \\
\text { students }\end{array}$ & $\begin{array}{l}\text { Teacher standing, } \\
\text { teaching whole } \\
\text { class, students } \\
\text { sitting }\end{array}$ & $\begin{array}{l}\text { RUI states that the classic and intuitive concept is that stopping demands a } \\
\text { time at the same position. The teacher moves to RUl's direction, near to the } \\
\text { researcher and the camera. While RUI speaks the teacher speaks "correct" } \\
\text { several times } \\
\text { NEY raises the question if the ball stops or does not stop, and RUI answers } \\
\text { negatively. NEY disagrees with RUI } \\
\text { Teacher says that the ball has not stopped. Teacher smiles in a relaxed way } \\
\text { The other students divide themselves between RUI / teacher's opinion and } \\
\text { NEY's opinion, with more tendency to agree with the former opinion. } \\
\text { Teacher takes the floor to speak and specifies that the problem is the } \\
\text { duration that does not exist in this case. The discussion evolves until the } \\
\text { teacher takes the floor to speak again } \\
\text { Teacher says, increasing his voice: Look, what I am trying draw attention } \\
\text { to... }\end{array}$ & $\begin{array}{l}\text { Discussing one } \\
\frac{\text { physics }}{\text { question }}\end{array}$ & $\begin{array}{l}\text { PG - Managing learning } \\
\text { opportunities } \\
\text { T- Classical mechanics } \\
\begin{array}{l}R-\text { Turns of talk are } \\
\text { usually short }\end{array}\end{array}$ \\
\hline
\end{tabular}


In table 2 we describe all the categories used to construct the "Narrations Frame" (table 3). Table 3 contains action 16 (descriptive) that represent the immediate context for actions 17 (dialogue) and 18 (argumentative) for class (activity) 9 that we will further analyze in more detail. The remaining categories presented in tables 2 and 3 are briefly discussed below.

In constructing the "Narrations Frame", after writing the narrations for each action and categorizing their discursive orientation, all the actions are read in a linear sequence, and each one is ascribed a name (a title), which should represent the teacher's action. Then the frame is read again in a linear order and ascribed with the "teacher's pragmatic didactic goals" for each action.

The pragmatic goals are inferred from discursive accomplishments and correlations within and between adjacent actions; so they can be related to a question such as "so, what happens after this?". The answer to this question can be found by seeking the discourse sequence flux. Then, one main pragmatic goal is ascribed to each action category. These goals are strongly related to action names, in the sense that they represent an intentional aspect of the narrations and descriptions of the teacher's actions. Thus, the action name provides cues to identify its corresponding pragmatic goal. This "pragmatic approach" is focused on the work accomplished.

We believe our "pragmatic approach" to infer goals is a relevant methodological step to interpret science classroom discourse. Despite the consensus that humans pursue goals when they act, identification and isolation of such goals is a difficult problem for analysts. Activity theory is strongly tied to human goal-directed actions, but it does not provide us with methodological tools to deal with goal identification. Our "pragmatic approach", in part, overcomes some of these difficulties because we infer goals from what is discursively accomplished. We are not concerned with whether, in reality, the teacher had such goals in mind when he acted; we are mainly focused on how we can address goals through correlations between discourse units and work accomplished. In this sense, our approach can serve as a coherent way to connect possible intentional aspects (goals) to real accomplishments. We consider this methodological choice an approach to face the goal-nature of human action without having to identify the real goals that individuals had in mind when they acted.

Finally, the actions are numbered and stamped with their initial time and temporal length according to the video time. In addition, the organization of interlocution pairs, arrangement of interlocutors, and the emergent themes developed are ascribed to each action. These aforementioned categories are all synthesized in table 2 and table 3. Also, in the last column there are the analyst's comments for each action. Such comments are of various kinds, from factual complementation until interpretations and evaluations of observable interactions. At this moment the analyst can be more partial. 


\section{Operations - Discursive Procedures to Accomplish Goals}

The "Propositional Frame" represents a more detailed level of analysis and data presentation, which maps the interactional discursive conditions. It is constructed from transcripts of the selected actions. In this frame, each turn of talk is divided into propositional units, which represent the small units of meaning we can identify from sociolinguistics features, notably contextualization cues such as pause, eye gaze, intonation, pitch (Gumperz, 1982), and also from other linguistic features, for example the presence of verbs, lexical cohesion, and referents (Adam, 2008). The main question posed here is "how and through what means is the goal in this action accomplished?".

To answer this question we group the propositional units into Discursive Didactic Procedures (DDPs). In this process, propositions that have "convergent meanings" are grouped in ways that we can interpret that they are "doing similar things". This categorization is similar to what linguists call micro speech acts (Adam, 2008), an idea that has its roots in John Searle's book "Speech acts: An essay in the philosophy of language" (1969). Then, these propositional groups (DDPs) is each given a name.

Our fundamental point here is that there are specific kinds of DDPs that realize different roles associated with and shaped by specific types of discursive orientations. At the same time, some kinds of DDPs accomplish some pragmatic didactic goals, which are associated with each discursive orientation in each action considered. It is important to consider that the teacher's DDPs are shaped by immediate conditions, such as discursive procedures, student's turns of talk, and even the teacher's previous DDPs. We acknowledge that discourse cannot be planned word by word; it often flows in a natural way, is always shaped by previous words, the discursive genre, the discursive orientation, and, of course, the specific goal pursued in one specific discursive situation. According to this perspective, humans are not fully aware of what they mean when they act and talk (Gee, 1999).

In fact, due to these characteristics of DDPs, we consider them mainly as operations. A relevant research purpose of our framework is to identify DDPs, their relations to action and goal accomplishment, and their characteristics and roles when they emerge in one or another discursive orientation. This should provide a means to help people gain more awareness through reflection about discursive practices in science classrooms. Such reflections may give rise to evaluations, criticisms, and transformations of teaching practices.

Instead of presenting a few, superficial DDPs of each discursive orientation (situated in specifics actions), we chose to present a thorough analysis of DDPs for the case of two actions (actions 17 and 18, see the synthesis in figure 1). Through an exchange of turns of talk in a science classroom, the teacher's first action (dialogue) lays the foundation for the accomplishment of the teacher's second action which develops argumentation. 
This focused presentation and discussion are provided to clarify how we address the identification of DDPs in the Propositional Frame and how DDPs can be related to discourse flux and discourse management.

A small segment of the Propositional Frame for the analyzed actions is shown in table 4 . The left side features the action number, the speaker's names (in capital) and the turns of talk with their propositional units; on the right side these propositional units are grouped as the teacher's DDPs and students' discursive procedures; the interval numbers refer to one set of propositions grouped as one teacher's DDP or one student's discursive procedure"

\section{ANALYSIS FROM DDPS PERSPECTIVE}

An analysis of the development of actions 17 and 18 (dialogue and argumentative actions, see the synthesis in figure 1) from the point of view of a teacher's DDPs will now be presented. These DDPs were selected because of their organizational role in the ongoing discourse, which enabled us to divide the discourse into large phases, such as opening, development, and closure of an argumentative discursive orientation. In the following, we will present these phases in a DDP structure and show how this structure can be integrated with other aspects of our methodology, thus constituting a model.

\section{Action 17 - Dialogue - Pragmatic goal: "Promote Argumentation”}

\section{DDPs: "Articulation and justification of two contradictory points of view"}

The teacher's main goal for this class was to discuss learning processes from a Piagetian perspective and relate this perspective to physics teaching. The teacher first assigned one task to be accomplished in groups of two or three students. The task concerned addressing the following questions: 1) What do we do when we learn new things? 2) How is human learning accomplished?

After discussing these two questions, the groups presented their answers, which were recorded on the whiteboard by the teacher. Throughout the presentations by the student groups, the teacher made various interventions and comments. In one of his interventions he noted the cognitive function of coordination of ideas. He then gave an example to illustrate this process. He drew on the whiteboard the movement of a ball launched upward and made a description of its movement and qualified "as strange" the zero velocity of the ball at one given moment. In action 16 the teacher provides a number of coordinated elements regarding the example at stake (see the $5^{\text {th }}$ column of table 3). The action 17 (see "Propositional Frame", table 4 for the next stretches of transcriptions presented) begins with one student, RUI, raising 
Table 4: A small segment of "Propositional Frame" (mapping operations) for the analyzed actions Legend: (words between parenthesis): analyst's comments; | words between bars |:

Simultaneous talk; the inclusion of commas signal the speaker's pause

\begin{tabular}{|c|c|c|c|}
\hline & SUBJECT TURN & $\begin{array}{l}\text { PROPOSITIONAL UNITS } \\
\text { (UNITS OF MEANING] }\end{array}$ & $\begin{array}{l}\text { TEACHER'S DISCURSIVE DIDACTIC } \\
\text { PROCEDURES (DDPS) AND STUDENTS' } \\
\text { DISCURSIVE PROCEDURES } \\
\text { (The teacher's DDPs and the students' discursive } \\
\text { procedures are a set of propositional units with } \\
\text { convergent meaning) }\end{array}$ \\
\hline & 1. RUI: & $\begin{array}{l}\text { 1. Teacher, } \\
\text { 2. let me make a comment here, } \\
\text { 3. when the ball velocity is zero, (in a upward launching) } \\
\text { 4. I already saw people saying this on TV, } \\
\text { 5. and in national exams corrections, } \\
\text { 6. the body stops at the peak point of the trajectory, }\end{array}$ & $\begin{array}{l}\text { 1. Interlocutor selection } \\
\text { 2. Request to participate } \\
\text { 3-6. Introduction of a problematic }\end{array}$ \\
\hline & 2. TEACHER: & $\begin{array}{l}\text { 1. Er, } \\
\text { 2. when we say that the body stops, }\end{array}$ & 1-2. Confirmation of the problematic \\
\hline & 3. RUI: & $\begin{array}{l}\text { 1. Ok, } \\
\text { 2. what does it mean 'to be stopped'?, }\end{array}$ & 1-2. Elaboration of a questioning \\
\hline $\begin{array}{l}\text { 乏 } \\
z \\
\text { 은 } \\
\text { U⿺乚一 }\end{array}$ & 4. TEACHER: & $\begin{array}{l}\text { 1. There are two senses, } \\
\text { 2. er, if er, } \\
\text { 3. if the sense of stopping, } \\
\text { 4. er, } \\
\text { 5. means you remain a time stopped, } \\
\text { 6. it is completely wrong, } \\
\text { 7. the problem is that thing is ambiguous, } \\
\text { 8. right?, } \\
\text { 9. Er, } \\
\text { 10. if means to have an instant with velocity zero, } \\
\text { 11. it stops, } \\
\text { 12. because it was rising, } \\
\text { 13. it is not anymore, } \\
\text { 14. but it is not coming down, } \\
\text { 15. in that instant it has velocity zero, } \\
\text { 16. isn't true? } \\
\text { 17. the problem is understand that it is just an instant, } \\
\text { 18. one infinitesimal time before and after it is in } \\
\text { movement, } \\
\text { 19. or rising, } \\
\text { 20. or coming down, }\end{array}$ & $\begin{array}{l}\text { 1-11. Articulation of two contradictory } \\
\text { points of view } \\
\text { 12-20. Justification of these two points } \\
\text { of view }\end{array}$ \\
\hline \multirow[t]{4}{*}{$\begin{array}{l}\frac{\infty}{z} \\
\frac{0}{6} \\
\frac{\cos }{4}\end{array}$} & 5. RUI & $\begin{array}{l}\text { 1. It is, } \\
\text { 2. because the intuitive, } \\
\text { 3. classic mechanic concept the person holds, (The } \\
\text { teacher and some students speak at the same time), } \\
\text { 4. is that 'stop' means demanding a time at the same } \\
\text { position, ITeacher: exactly| } \\
\text { 5. and actually it does not occur, |Teacher: this doesn't } \\
\text { occurs| } \\
\text { 6. there is not any time, |Teacher: nol } \\
\text { 7. that it remains in the same position, |Teacher: nol } \\
\text { 8. if you do the limit there, |Teacher: correct| } \\
\text { 9. the limit tends to zero there, |Teacher: correct| } \\
\text { 10. this has not, } \\
\text { 11. so er, } \\
\text { 12. this questions is interesting, } \\
\text { 13. stop a at the peak point, } \\
\text { 14. it does not stops at the peak point, }\end{array}$ & $\begin{array}{l}\text { 1-10. Justification to one specific point of view } \\
\text { 11-12. Qualification of the raised questioning } \\
\text { 13-14. Articulation of his opinion } \\
\text { Teacher: | 4-9. Confirmation of one's point } \\
\text { of view I }\end{array}$ \\
\hline & 6. NEY & 1. It stops or does not stop?, & 1. Raising of a questioning \\
\hline & 7. RUI & 1. It does not stop!, (ISIS starts to laugh) & 1. Restatement of his opinion \\
\hline & 8. NEY & $\begin{array}{l}\text { 1. Stops!, } \\
\text { 2. With zero velocity the body is stopped, (ISIS laughs } \\
\text { again, several students speak at the same time) }\end{array}$ & $\begin{array}{l}\text { 1. Articulation of a counter-opinion } \\
\text { 2. Justification of counter-opinion }\end{array}$ \\
\hline
\end{tabular}


the following question (expressions in parentheses seek to offer clarification and contain analyst's explicit comments; words in capitals in the beginning of each turn represent the speaker's name; the inclusion of commas signal the speaker's pauses):

1 - RUI: Teacher, let me make a comment here, when the ball velocity is zero, (in an upward launching) I already saw people saying this on TV, and in national exams corrections, the body stops at the peak point of the trajectory,

2 - TEACHER: Er, when we say that the body stops,

3 - RUI: Ok, what does it mean 'to be stopped'?,

4 - TEACHER: There are two senses, er, if er, if the sense of stopping, er, means you remain a time stopped, it is completely wrong, the problem is that thing is ambiguous, right?, Er, if means to bave an instant with velocity zero, it stops, because it was rising, it is not anymore, but it is not coming down, in that instant it has velocity zero, isn't true? The problem is understand that it is just an instant, one infinitesimal time before and after it is in movement, or rising or coming down,

In the fourth turn of talk, the teacher answers RUI's question by suggesting that there could be two senses to the "stop" (procedure of "articulation of two contradictory points of view"), and then he presents justifications for each one (procedure of "justification of these two points of view").

The teacher constructed two different justifications for the opposite views (the ball at rest or in movement at the peak point of its trajectory, see turn 4). We infer from his next procedures (see turn 9 (below)) that he did not agree with the view that the ball has stopped at the peak point. However, at this point he offered justified responses to both points of view.

These procedures, in their specific use by this teacher, allow us to see them as a contribution to establish an argumentative discursive orientation with interactions with students. This connection of the discursive procedures with the argumentation is justified by the fact that the teacher could have given only one answer (his own opinion) in order to clarify the question; instead, he presents and justifies two opposing opinions, that is, he gives space for the emergence of students' partialities to one or other opinion, which can give space to opposing positions in the students' speech. In this sense, as they are stated in the same turn by the teacher, the two justified opposite opinions are given symmetric status. If we consider the privileged role of the teacher, this characteristic is fundamental to avoid locking the students' opinion to one authority: That of the teacher himself. In the moment of constructing the two contradictory points of view, the teacher, in some sense, gives up his partiality (and his authority) to guide the discussion in a more polyphonic way, in which two contradictory points are presented and justified.

This discussion is related to the pragmatic goal of "promoting argumentation". The next action is an argumentative one, consistent with our definition of pragmatic goal (i.e., goals derived from discursive correlations between actions and immediately conditions). Therefore, these two DDPs are 
related to the opening moment of an argumentation in which the teacher deals with a potential argumentative discursive orientation and to which he gives all the discursive support to its establishment in a well-defined problem space, restricting the polyphony in certain aspects, in the case analyzed here, by restricting the conversation to the definition of "being at rest".

\section{Action 18 - Argumentative - Pragmatic Goal: "Manage Learning Opportunities"}

\section{DDP: "Confirmation of one's point of view"}

As was demonstrated in a previous paper (Nascimento, Plantin \& Vieira, 2008), one technique used by this teacher to validate the students' arguments is repetition and confirmation. The following discourse segment exemplifies how the teacher accomplished this validation (the text between bars are signify simultaneous talk by the teacher occurring during the student's remarks):

5 - RUI: It is, because the intuitive, classic mechanics concept the person holds, (the teacher and some students speak at the same time) is that 'stop' means demanding a time in the same position, |Teacher: exactly $\mid$ and actually it does not occur, |Teacher: this doesn't occur | there is not any time, |Teacher: no | that it remains in the same position, |Teacher: no | if you do the limit there, |Teacher: correct| the limit tends to zero there, |Teacher: correct| this has not, so er, this question is interesting, stop at the peak point, it does not stop at the peak point,

At the same time the teacher repeats and confirms RUI's talk in turn 5, he physically moved towards RUI (initially the teacher was quite far from him). In this sense he showed interest in RUI's statements and recognizes his discursive dominance over the other students in that moment.

Empirically, this procedure was chronologically associated with argumentation development, since the basis and limits of the discussion had already been set by the teacher during the two previous procedures. It can be theoretically justified that, in validating RUI's argument at this point, the teacher contributed to the establishment of a preferential point of view, without, however, defining in a decisive way the endpoint of the discussion. In other words, the teacher left his "neutrality position" in turn 5 and assumed one specific point of view, so his assumed partiality gives rise to the development of the contradictions placed in the opening phase, as we can see in NEY's talk in turn 8:

6 - NEY: It stops or does not stop?,

7 - RUI: It does not stop!, (ISIS starts to langh)

8 - NEY: Stops! With zero velocity the body is stopped, (ISIS laughs again, several students speak at the same time)

9 - TEACHER: It is not stopped,

Thus, this procedure ("Confirmation of one's point of view") in turn 5 intensified the initial contradictions just because the teacher began to be partial 
to RUI's perspective. It can be understood that in this moment some partialities emerge, and as a consequence, they contribute to the emergence of others partialities, as is the case with the entrance of NEY into the discussion (see turns 6 and 8). Therefore, the initial contradictions set off a discussion that became more heated over time (see turns 6, 7,8 and 9). These characteristics place this moment at the development phase of the argumentation.

\section{DDPs: "Articulation of a point of view" and "Justification of this point of view"}

In the eighth turn of talk presented above, NEY disagreed with RUI and the teacher, arguing that if the velocity is zero, then the ball must have stopped.

After some justification from the teacher and RUI supporting the point that the ball has not stopped, NEY questioned the status of something reified in the community of physics students: the zero velocity of the ball at the peak point of its trajectory (see turn 19). The following transcripts illustrate how this teacher deals with this unusual moment:

\footnotetext{
19 - NEY: Then the velocity is not zero,

20 - TEACHER: The velocity is zero, in that instant the velocity is zero, (some students speak at the same time in an attempt to justify that the ball velocity is zero)

21 - NEY: There is no way, (several students talk at the same time in attempts to justify why the ball velocity is zero)

22 - TEACHER: Look, the velocity is zero, because graphically you can see this, (the teacher refers to the velocity $v$ s. time graph drawn on the whiteboard) the velocity is decreasing and at a determined moment it increases, but in the opposite direction so it passes through velocity zero between one thing and another, right?, In one instant, but it does not stop, if you take any tiny time after or before, if you take the integral of this here, it moved, there was some movement there,
}

It is evident by the transcription that the knowledge of zero velocity is reified (just because several students try to justify that the velocity is in fact zero, as we can attest in turn 21). It seems that NEY cannot distinguish the concept of movement from the concept of instantaneous velocity. In that way, he deduced that, if there is movement of the ball, as the teacher and RUI suggested, then it could not have zero velocity. In other words, NEY inverted the causality order of his argument in turn 8 and ended up deducting the opposite of what he argued in the beginning. The teacher, attentive to NEY's discursive contradiction and to his incorrectness of physics knowledge, articulated and justified one point of view: the zero velocity of the ball (see turn 22).

With these procedures the teacher moved the argumentation to another focus: he claimed and later justified that the ball's velocity is zero (but not that the ball came to rest) because he was attentive to a physics knowledge gap on the part of NEY. At this point, the teacher's use of these DDPs collaborated to close one secondary and incidental argumentative zone, before returning to the main argumentative focus, that is, if the ball has stopped or has not stopped at the peak point.

These two DDPs (see turn 22) are clearly located in the development 
phase, since they meet the function of closing a "ramification" that emerged from the main discussion. From the teacher's perspective, this ramification must be well clarified and established to address the gap in the student's knowledge (information taken from the second interview with the teacher). This brings us to the fact that a didactically orientated argumentation must have a focus, for if not we could have several argumentative ramifications that do not close. In other words, at this point, these two DDPs are used to decrease polysemy, which, in turn, could lead to unwanted dispersion. It is interesting to note that in the opening phase polysemy is welcome, just to create space for argumentation. Now, at this point, polysemy is decreased in order to avoid this dispersion, tangential to the main line of discussion.

\section{DDP: Establishment of the last word}

The teacher, after nearly four minutes of discussion, decided to redirect the students' attention to the immediate previous subject of discussion: the processes of learning and coordination of ideas regarding the phenomena of vertical movement of a ball. To do so, he used his asymmetrical position and established the last word for the discussion (see turn 25):

25 - TEACHER: Look, (the teacher increases the volume of his voice) what I am trying draw attention to, (the teacher makes a "shbh" sound in order to ask for silence) is that when we describe this story we use the coordination of a number of ideas, of distance, of time, of dividing this in infinitesimals, of vectors, of representations, of graphics, right?, Ideas of rates of change, in other words, we use a coordination of ideas, to give sense, a new sense, to this phenomenon so familiar, so trivial, right? To launch an object upward, and let it fall, right?, Ok?,

The teacher made use of this procedure to close the discussion even without consensus when he asked for silence with the non-lexical expression "shhh", raised his voice, and established a theme change moving from the discussion of physics to metadiscourse, of how they were thinking about the problem as a coordination of ideas. Thus, these three discursive resources (i.e., non-lexical expression, raised voice, theme change) work together in order to "establish the last word."

It is worth noting here that this action clearly shows a continuous dynamic between contrapositions of ideas and reciprocal justifications, and can be considered as an argumentative action. We ascribe to it the pragmatic goal "manage learning opportunities" because the debate established was a situation that demanded individuals to access, evaluate, and criticise others' positions and justifications, including those of the teacher. These mutual "access, evaluation and criticize" dynamics were strongly shaped by the teacher who took a fundamental role as a participant and manager. Such dynamics constitute what we are calling learning opportunities; and, in fact, these dynamics were a necessary requirement for individuals in order to participate in the established argumentation in a continuous creation of justifications and contradictions. 
In the second interview with the teacher it could be understood why he decided to finish the discussion at that point:

".... What there was to learn from that situation had already been learned, and then became just personal opinion to say one thing or another in classroom". (extracted from the second interview with the teacher)

This quote evinced that he recognized there were "learning opportunities" in the argumentative action, although he also signaled that these opportunities were "saturated" at some point, and this was his reason for finishing the discussion.

\section{INTEGRATING THE DISCURSIVE PROCEDURE STRUCTURE INTO THE ANALYTICAL MODEL}

With the analyzes made with the three frames, and based on the thorough analysis of the selected DDPs presented earlier, it is possible to synthesize them into an integrated and relational structure represented in figure 1. The left side of figure 1 presents, in a schematic way, some aspects of the whole methodology, which can be derived from the articulation of the three frames presented earlier: The whole class \# 9 as one activity (see table 1 ); some selected actions that are related to a main pragmatic goal and to one specific discursive orientation (action 16 - descriptive; action 17 - dialogue; and action 18 - argumentative; see table 3); and the selected teacher's DDPs (i.e., operations) as means for actions accomplishment (actions 17 and 18). This representation is meant to provide a model which allows to grasp and make sense of the discursive genre of science classrooms as a kind of a continuous description of its discursive rhythm flow.

The right part of figure 1 derives from our analysis in relation to the teacher's DDPs presented above, showing the DDPs structure within the dialogue and argumentative actions. As we have suggested, in relation to the analyzed DDPs and in order to make the figure more understandable, some phases have been ascribed to it, namely opening, development, and closure phases. 
Figure 1: The model for a discursive segment from class 9 and the procedural structure for selected Actions

\section{Activity (class) 9}

Motive: Piagetian approach

\section{Action 16 - Descriptive}

Pragmatic goal:

Summarize information

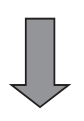

Action 17 - Dialogue

Pragmatic goal:

Promote argumentation

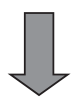

\section{Action 18 - Argumentative}

Pragmatic goal:

Manage learning opportunities

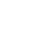

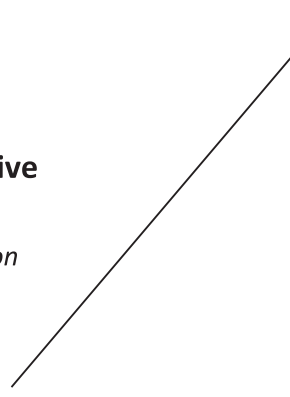


This model demonstrates how specific types of DDPs and their particular roles can be situated in a dominant discursive orientation in each action where they appear and how they can be related to pragmatic didactic goal accomplishments. We claim that the main feature of the framework when applied to data is to give us a descriptive view about important relationships among elements of the triad "discursive orientations/goals/DDPs" that are all represented in this model. For the purpose of making clear the steps taken from data analysis to this model, we comment upon the sources of such elements shown in this model.

The actions with discursive orientations and their goals are derived from analysis performed with the "Narrations Frame". The DDPs in the model shown for the selected actions are derived from analysis carried out with the "Propositional Frame" which were presented in the previous section. The main point is that the model is a representative way to make it easier to follow the relationships and discursive flow of these elements in a schematic way (discursive orientations/goals/DDPs).

To conclude this section we will raise questions that can be answered with outcomes from the application of the framework and represented in the model: Which pragmatic goals are more related to one discursive orientation? How is each discursive orientation managed and accomplished by which DDPs? What types of DDPs are more related and in sync with one type of discursive orientation?

We believe that teachers and researchers could use these outcomes represented in the model to develop more awareness about classroom discursive practices. They would be able to better distinguish and understand which DDPs are more consistent with some discursive orientations and related actions/goals, and in this sense the model can be viewed as a meta-instrument to help them to describe and understand discursive teaching practices.

\section{DISCUSSION}

The application of the framework provided both a broad analysis examining discourse practices over time, as well as a more thorough and situated analysis of the moment-to-moment interactions. The different levels of analysis of an activity (activity, action and operation) were useful to perform this movement from broad to situated analysis and to coordinate our categories with those from textual linguistics and sociolinguistics.

The incorporation of these levels in the analytical framework was performed by the use of different frames, with increasingly specified analysis informed by the context of the more general analysis. This process is iterative so that each of the levels can be revisited and reconsidered given new interpretations, thus providing feedback and corrections.

Until recently, ethnographic studies of discourse in science classrooms contexts had largely based analysis on a time scale criteria (with temporal units) and thematic content of talk and action to map discourse events. As an alternative, our 
analytic framework proposes a methodology to divide and organize discourse in levels of analysis, based on psychological criteria, according to Leont'ev's proposal structure for human activity. According to our methodology, one teacher's action could lasts seconds, or a number of minutes, once it is specified not by temporal definitions a priori, but by its subordination to one teacher's goal. Similarly, we can consider the operation as subordinated to methods and conditions of action accomplishment. We recognize this new approach to map and organize the discourse analysis is relevant to deal with the large amount and diversity of data generated through extensive research regarding discourse interactions in science classrooms contexts. Also, it is expected this new approach could be useful to clarify more the roles of discourse interactions in science classrooms and the teacher's roles as a manager of these interactions.

The incorporation of the sociolinguistics approach into the framework contributed to introduce an emic perspective through the use of contextualization cues to segment classroom conversations at the action and operation levels. In this sense, sociolinguistics provides means to consider the participants perspectives, thus increasing the validity of the discourse analysis.

The textual linguistics field provided criteria to develop and introduce the concept of "discursive orientation," which gives space for possibilities and constraints to human action and thought and therefore can be viewed as a psychological tool. Thus, it is acknowledged that each discursive orientation offers specific "learning opportunities" to the students.

The framework "core" provides ways to situate DDPs in different discursive orientations and understand how these DDPs can accomplish specific pragmatic didactic goals, which ultimately can be associated with the constructed discursive rhythm in science classrooms. In this paper the case has been made for dialogue and argumentative DDPs, and we demonstrated how the framework operated in integrated and articulated ways to provide a situated view of these DDPs. Such situated view is fundamental to our approach, which is informed by, but also can inform, an activity theory perspective on human learning and development.

As we mentioned before, our previous studies (Vieira \& Nascimento, 2009a) revealed that undergraduate physics students and physics teachers do not have clear concepts of an argumentative discursive orientation and how it differs from an explicative one. They do not possess clear ideas of which goals each one can accomplish, or how each discursive orientation can be achieved and maintained. Accordingly, the framework "core" triad "discursive orientation/ goals/DDP" contributes to inform research in dealing with this problem. Also, the framework's focus on work accomplished led us to deal with some difficult problems by means of a "pragmatic approach", as was the case in considering and identifying pragmatic goals from real discursive correlations.

The framework situated view, developed from activity theory, contributes to research examining procedural discursive knowledge in science classrooms. However, studies regarding discourse in science classrooms have mainly relied on 
understanding the roles of patterns of interactions such as IRF and IRE, giving little attention to how operations are constructed through discourse processes. In this paper, we focused in DDPs rather than patterns of interactions, but we acknowledge that there are relationships between both; that is, one should question how DDPs constitute some patterns in specific discursive orientations. Thus, the concepts of patterns and procedures can be complementary when considering the ways that everyday life in science classrooms is constructed through interaction.

It is worth noting that the DDPs roles are fluid because they can serve multiple didactic goals, as is expected for operations from an activity theory point of view. For example, consider from the analysis we performed, the DDP "justification of a point of view". In its first appearance, this DDP fulfilled the role of encouraging argumentation. In a later appearance, it restricted argumentation. Thus, in different moments and within different discursive orientations distinctive roles for the same DDP could be identified, first to increase polysemy and second to restrict it. This is an important outcome from the framework application and it is acknowledged that there is the need to apply it to data analysis in a thorough way, in order to learn more about situated DDPs and their roles.

At this point, we believe that the framework and the discussions and outcomes that resulted from its application can contribute to the identification of possibilities of discourse management in science classrooms. According to this perspective, a set of situated DDPs and goals can serve as references for other teachers in the context of science teacher education and should be a way to increase their awareness concerning how they can deal with discourse in situated practices, provide space for reflections, allow for criticisms and transformations of ideas.

The framework does have some limitations that suggest directions for further research development. First, strong criteria need to be developed to confirm the first categorization of each action in terms of discursive orientation. In this paper only strong criteria for the argumentation case are presented; all other discursive orientations are discussed with only loose criteria for an initial and rough identification. In fact, we are currently working on this issue, relying on textual linguistics as a main reference. In this endeavor we are seeking to manage empirical factors of science classroom discourse which, it is believed, should provide the specific indices and cues to clarify these criteria for these learning environments.

A second important limitation identified in this framework is the lack of a complete set of criteria to recognize a full range of patterns for DDPs in science classrooms. Such a full set requires additional data analysis and attention to the emerging patterns from classroom discourse.

A third limitation concerns the analytic construction of the emic perspective in the framework. The perspective was derived from actions and operations taken by the teacher and through interviews, but it remains to be seen if including this teacher, or science teachers in general, in the action analysis, would further the emic perspective and advance understanding of the teachers' actions. Such an approach may inform the emic perspective for the action category, improving the 
fidelity of the framework as recognized by insiders, which Gee (1999) claims is an important criterion for validation.

Finally, it is expected that the framework could be generalized to analyze different classrooms with different research purposes. The generalisation itself presupposes transformation and adaptation of the framework and only future utilizations of it can reveal if it has the necessary flexibility to accomplish this endeavor. In conclusion, we believe that if the framework meets this requirement it could be considered as useful and with potential to have real impact in teachers' practices and to researchers' understanding of discourse in science classrooms.

We acknowledge Christine M. Cunningham, Vice-President of Museum of Science, Boston, US, for the language revision of this paper.

\section{NOTES}

1 This research was financially supported by Conselho Nacional de Desenvolvimento Científico e Tecnológico (CNPq) and Coordenação de Aperfeiçoamento de Pessoal de Nível Superior (CAPES).

${ }^{2}$ We use the word "didactic" as related to teaching, as is the case for the most Indo-European languages.

3 Explanation and explanatory are more common words in English. Hereinafter, when we are referring specifically to sequences we will use the term "explicative". This is the term in English that is more akin to the original term in French used by Adam (1992). Also, as discussed further, we will use the term "explicative" when dealing with "discursive orientations".

${ }^{4}$ Or normative.

\section{REFERENCES}

Adam, J. M. (1992). Les textes: Types et prototypes. Paris, Nathan.

Adam, J. M. (2008). A lingüistica textual: Introducão à análise textual dos discursos. São Paulo, Cortez.

Bakhtin, M. (1986). Speech genres and other late essays. Austin: University of Texas Press.

Billig, M. (1996). Arguing and thinking: A rhetorical approach to social psychology. Cambridge: Cambridge

University Press.

Bronckart, J. P. (1996). Activité langagière, textes et discours: Pour un interactionisme socio-discursif. Neuchâtel:

Delachaux et Niestlé.

Castanheira, M. L., Crawford, T., Dixon, C., \& Green, J. L. (2001). Interactional ethnography: An approach to studying the social construction of literate practices. Linguistics \& Education, 11, 353-400.

Cazden, C. (2001). Classroom discourse: The language of teaching and learning (2nd ed.). Portsmouth, NH: Heinemann.

Charaudeau, P., \& Maingueneau, D. (2002). Dictionnaire d'Analyse du Discours. Paris: Seuil, 2002.

Denzin, N. K., \& Lincoln, Y. S. (2000). Introduction: The discipline and practice of qualitative research. In Denzin, N. K., \& Lincoln, Y. S. (Eds.), Handbook of Qualitative Research, Thousand Oaks: SAGE Publications, p. 1-28.

Engeström, Y. (1999). Activity Theory and Individual and Social Transformation. In Y. Engeström, R. Miettinen, \& R.-L. Punamaki (Eds.), Perspectives on activity theory (pp. 19-38). Cambridge, UK: Cambridge University Press. 
Erduran, S., Simon, S., \& Osborne, J. (2004). TAPing into Argumentation: Developments in the Application of Toulmin's Argument Pattern for Studying Science Discourse. Science Education, 88(6), 915-933.

Gee. J. P. (1999). An introduction to discourse analysis: Theory and method. New York: Routledge.

Green, J., \& Wallat, C. (1981). Mapping instructional conversations: A sociolinguistic ethnography. In J. Green \& C. Wallat (Eds.), Ethnography and language in educational settings (pp. 161-205). Norwood, NJ: Ablex.

Gumperz, J. J. (1982). Discourse strategies. Cambridge: Cambridge University Press.

Gumperz, J. J. (2001). Interactional sociolinguistics: A personal perspective. In D. Schiffrin, D. Tannen, \& H. E. Hamilton (Eds)., Handbook of discourse analysis (pp. 215-228).

Hymes, D. (1974). Foundations of sociolinguistics: An ethnographic approach. Philadelphia: University of Pennsylvania.

Jiménez-Aleixandre, M. P., \& Erduran, S. (2008). Argumentation in science education: an overview. In S. Erduran, \& M. P. Jiménez-Aleixandre (Eds.), Argumentation in science education: Recent developments and future directions (pp. 3-27). Dordrecht: Springer.

Kelly, G. J. (2007). Discourse in science classrooms. In S. Abell, \& N. Lederman (Eds.), Handbook of Research on Science Education (pp. 443-470). Lawrence Erlbaum Associates.

Kincheloe, J. (2001). Describing the bricolage: Conceptualizing a new rigor in qualitative research. Qualitative Inquiry, 7(6), 679-692.

Lave, J., \& Wenger, E. (1991). Situated learning: Legitimate peripheral participation. Cambridge: Cambridge University Press.

Lemke, J. L. (1990). Talking science: Language, learning and values. Norwood, NJ: Ablex.

Leont'ev, A. N. (1978). Activity, consciousness, and personality. Englewood Cliffs, NJ: Prentice-Hall.

Mehan, H. (1979). Learning lessons: Social organization in the classroom. Harvard University Press: Cambridge, MA.

Mortimer, E., \& Scott, P. (2003). Meaning Making in Secondary Science Classrooms. Maidenhead, England: Open University Press.

Nascimento, S. S., Plantin, C., \& Vieira, R. D. (2008) A validação de argumentos em sala de aula: um exemplo a partir da formação inicial de professores de física. Investigações em Ensino de Ciências, 13(2), 169-185.

Ogborn, J., Kress, G., Martins, I., \& McGillicuddy, K. (1996). Explaining science in the classroom. Buckingham: Open University Press.

Plantin, C. (2005). L'argumentation. Paris: Presses Universitaires de France.

Roth, W-M, Lee, Y-J. (2007). "Vygotsky's neglected legacy": cultural-historical activity theory. Review of Educational Research, 77 (2), 186-232.

Searle, J. (1969). Speech acts. Cambridge: Cambridge University Press.

Sinclair, J., \& Coulthard, M. (1975). Towards an analysis of discourse: The language of teachers and pupils. London: Oxford University Press.

Toulmin, S. (1958). The uses of argument. Cambridge, MA: Harvard University Press.

Vieira, R. D. (2011). Discurso em salas de aula de ciências: Uma estrutura de análise baseada na teoria da atividade, sociolinguistica e linguística textual. Tese de Doutorado: Faculdade de Educação, UFMG.

Vieira, R. D., \& Nascimento, S. S. (2008). Avaliações de argumentação de licenciandos em física sobre um episódio de estágio curricular: Em que critérios eles se baseiam? Atas do XI EPEF, Curitiba, 01-12.

Vieira, R. D., \& Nascimento, S. S. (2009a). Uma proposta de critérios marcadores para identificação de situações argumentativas em salas de aula de ciências. Caderno Brasileiro de Ensino de Física, 26 (1), 81-102.

Vieira, R. D., \& Nascimento, S. S. (2009b). Uma visão integrada dos procedimentos discursivos didáticos de um formador em situações argumentativas de sala de aula. Ciência e Educaşão, 15(3), 443-457. 
Vieira, R. D., \& Nascimento, S. S. (2011). Discourse in science teacher education: a methodological approach to segment discourse in levels. Ebook proceedings of the $9^{\text {th }}$ ESERA conference, 108-112.

Vygotsky, L. S. (1986). Thought and Language. Cambridge, MA: The MIT Press.

Werlich, E. (1976). A text Grammar of English. Quelle \& Meyer.

Wertsch, J. V. (1991). Voices of the mind: A sociocultural approach to mediated action. Cambridge, Mass.: Harvard University Press. 